\title{
ANALISIS PENGARUH PENGALAMAN DAN PENGGUNAAN INTUISI AUDITOR DALAM MENDETEKSI KEKELIRUAN
}

\author{
Oleh: \\ Novitha Rosaliana Mariane Wuisan \\ Agus T. Poputra \\ Victorina Z. Tirayoh \\ Fakultas Ekonomi dan Bisnis, Jurusan Akuntansi \\ Universitas Sam Ratulangi Manado \\ email:vhitha_p@rocketmail.com
}

\begin{abstract}
ABSTRAK
Profesi akuntan merupakan profesi yang dilandaskan kepercayaan dari masyarakat. Namun dengan terjadinya kasus-kasus laporan keuangan oleh indikator serta terungkapnya solusi antara Kantor Akuntan Publik dengan kliennya agar lolos go publik menyebabkan masyarakat belum sepenuhnya menaruh kepercayaan terhadap profesi akuntan latar belakang institusional dan hukum yang berbeda yang membedakan audit sektor publik dengan sektor swasta, dimana audit sektor publik mempunyai prosedur dan tanggung jawab yang berbeda serta peran yang lebih luas dibandingkan audit sektor swasta. Hal ini dapat diketahui bahwa auditor pemerintah dalam melaksanakan tugasnya tidak hanya memeriksa dan menilai kewajaran laporan keuangan sektor publik tetapi juga menilai ketaatan aparatur pemerintah terhadap undang-undang dan peraturan yang berlaku. Tujuan penelitian ini adalah untuk mengetahui pengaruh pengalaman dan penggunaan intuisi auditor dalam mendeteksi kekeliruan pada Inspektorat Provinsi Sulawesi Utara. Metode analisis yang digunakan dalam penelitian ini adalah analisa regresi berganda. Hasil penelitian menunjukan bahwa pengalaman dan penggunaan intuisi auditor berpengaruh dalam mendeteksi kekeliruan pada Inspektorat Provinsi Sulawesi Utara. Hasil analisa korelasi ganda yang diperoleh bahwa hubungan antara variabel pengalaman dan penggunaan intuisi auditor dalam mendeteksi kekeliruan pada Inspektorat Provinsi Sulawesi Utara cukup kuat dan saling berpengaruh.
\end{abstract}

Kata kunci : pengalaman, penggunaan intuisi dan mendeteksi kekeliruan

\begin{abstract}
Accounting profession is aprofession that is based on the public trust. But with the case - the case of the financial statements and the disclosure of the indicator solutions between the public account firm and its clien in order to qualify to go public that the commmunity is not fully confident in the accounting profession. Institutional background and different laws that distinguish public sector audit by the private sector, where public sector auditing procedures and have different responsibilities and a broader role than the private sector audit. It can be seen that govemment auditor in carrying out their duties not only examine and assess the fairness of the financial statment of the public sector but also govemmen officials to assess compliance laws - laws and regulations. Purpose of this study was determine the effect of auditor experience and use intuition in detecting errors in the North Sulawesi Provincial Inspectorate. Methodes of analysis used in this study is multiple regression analysis. Result showed that experience and use intuition influential auditors in detecting errors in the North sulawesi Provincial Inspectorate. Multiple correlation analysis shows that the relationship between the variables of experience and use intuition auditors in detecting errors in the North Sulawesi Provincial Inspectorate strong enough.
\end{abstract}

Keywords : experience, the use of intuition and detecting errors 


\section{Latar Belakang}

\section{PENDAHULUAN}

Pemberian otonomi dan desentralisasi menurut UU RI No 32 tahun 2004 yang luas nyata dan bertanggung jawab kepada pemerintah kota dan juga provinsi tidak hanya membawa konsekuensi terhadap perubahan pola dan sistem pengawasan dan pemeriksaan, tetapi juga memberikan tuntutan kepada aparatur pemerintah kota dan provinsi untuk lebih terbuka, transparan dan bertanggung jawab atas keputusan yang dibuat. Maka dalam pemerintahan sendiri juga sudah mulai ada perhatian yang lebih besar terhadap penilaian kelayakan praktik manajemen pemerintahan. Hal ini mencakup perlunya dilakukan perbaikan sistem akuntansi manajemen, sistem akuntansi keuangan, perencanaan keuangan, pembangunan, sistem pengawasan dan pemeriksaan serta berbagai implikasi finansial atas kebijakankebijakan yang dilakukan pemerintah.

Noviyani dan Bandi (2009) menyatakan pengalaman sangat penting diperlukan dalam rangka kewajiban seorang pemeriksa terhadap tugasnya untuk memenuhi standar umum audit. Untuk membuktikan keahliannya atau profesionalisme seorang auditor harus memiliki pengalaman dalam praktek audit, karena auditor yang tidak berpengalaman akan melakukan kesalahan yang lebih besar dibandingkan dengan auditor yang berpengalaman. Auditor-auditor yang berpengalaman dapat ditemui pada ihnstansi pemerintah terutama pada kantor Inspektorat Provinsi Sulawesi Utara. Instansi ini merupakan unsur pengawas penyelenggaraan pemerintahan daerah yang bertanggung jawab langsung pada gubernur.

\section{Tujuan Penelitian}

Tujuan penelitian ini adalah:

1. Untuk mengetahui pengaruh pengalaman auditor dalam mendeteksi kekeliruan pada Inspektorat Provinsi Sulawesi Utara.

2. Untuk mengetahui pengaruh penggunaan intuisi auditor dalam mendeteksi kekeliruan pada Inspektorat Provinsi Sulawesi Utara.

\section{Auditing (Pemeriksaan)}

\section{TINJAUAN PUSTAKA}

Arens (2010:2) menyatakan bahwa auditing adalah proses pengumpulan dan pengevaluasian bahan bukti tentang informasi yang dapat diukur mengenai suatu entitas ekonomi untuk menentukan dan melaporkan kesesuaianinformasi yang dimaksud dengan kriteria-kriteria yang dimaksud yang dilakukan oleh seorang kompeten dan independen. Definisi audit yang berasal dari ASOBAC (A statement of Basic Auditing Concept) yang dikutip dari (Halim 2004:1) adalah suatu proses sistematik untuk menghimpun dan mengevaluasi buktibukti secara obyektif mengenai asersi-asersi tentang berbagai tindakan dan kejadian ekonomi untuk menentukan tingkat kesesuaian antara asersi-asersi tersebut dengan kriteria yang telah ditentukan dan menyampaikan hasilnya kepada para pemakai yang berkepentingan. Soekrisno (2002:1) menyatakan bahwa auditing adalah suatu pemeriksaan yang dilakukan secara kritis dan sistematis oleh pihak yang independen terhadap laporan keuangan yang telah disusun oleh manajemen, beserta tataran-tataran pembukuan dan bukti-bukti pendukungnya dengan tujuan untuk dapat memberikan pendapat mengenai kewajaran laporan keuangan tersebut. Auditing merupakan salah satu bentuk atestasi.

Pemeriksaan akuntansi menurut Mulyadi (2004 : 9) yaitu suatu proses sistematik untuk memperoleh dan mengevaluasi bukti secara obyektif mengenai pernyataan-pernyataan tentang kegiatan dan kejadian ekonomi dengan tujuan untuk menetapkan tingkat kesesuaian antara pernyataan-pernyataan tersebut dengan kriteria yang telah ditetapkan, serta penyampaian hasil-hasilnya kepada pemakai yang berkepentingan. Auditing menurut Yusuf (2004 : 11) adalah proses yang di tempuh oleh seseorang yang kompeten dan independen agar dapat menghimpun dan mengevaluasi bukti-bukti mengenai informasi yang terukur dari suatu entitas (satu) usaha untuk mempertimbangkan dan melaporkan tingkat kesesuaian dari informasi yang terukur tersebut dengan yang telah ditetapkan.

\section{Jenis - jenis Audit}

Ada 3 jenis audit menurut Arens (2010:2).

1. Audit atas laporan keuangan/Financial Audit adalah yang bertujuan untuk menentukan kesesuaian informasi terukur yang akan diverifikasi dengan kriteria tertentu seperti standat akuntansi yang berlaku umum (PSAK). 
2. Audit Operasional adalah penelaahan bagian dari prosedur atau metode operasi suatu organisasi untuk menilai efisiensi dan efektifitasnya.

3. Audit ketaatan adalah audit atas ketaatan auditee terhadap prosedur atau aturan tertentu yang telah ditetapkan baik aturan yang ditetapkan perusahaan maupun aturan yang ditetapkan oleh atau dengan pihak luar seperti pemerintah, bank, kreditor, atau pihak lainnya.

Mulyadi (2004:82) menyatakan, jenis-jenis audit berdasarkan luas pemeriksaannya dibagi menjadi.

1. General Audit (Pemeriksaan Umum)

Suatu pemeriksaan umum atas laporan yang dilakukan oleh kantor akuntan publik yang independen dengan tujuan untuk bisa memberikan pendapatan mengenai kewajaran laporan keuangan secara keseluruhan.

2. Spesial Audit (Pemeriksaan Khusus)

Suatu pemeriksaan terbatas yang dilakukan oleh kantor akuntan publik yang independen pada akhir pemeriksaannya auditor tidak perlu memberikan pendapat terhadap kewajaran laporan keuangan secara menyeluruh.

Jenis audit berdasarkan jenis pemeriksaannya (Mulyadi 2004:83).

a. Manajemen Audit (Operational Audit)

Suatu pemeriksaan terhadap suatu perusahaan, termasuk kebijakan akuntansi dan kebijakan operasional yang telah ditentukan oleh manajemen perusahaan, untuk mengetahui apakah kegiatan opersi tersebut sudah secara efektif, efisien dan ekonomis.

b. Pemeriksaan Ketaatan (Compliance Audit)

Pemeriksaan yang dilakukan untuk mengetahui apakah perusahaan sudah menaati peraturan-peraturan dan kebijakan yang berlaku, baik yang ditetapkan oleh pihak intern perusahaan (manajemen, dewan komisaris) maupun pihak ekstern.

c. Pemeriksaan Intern (Internal Audit)

Pemeriksaan dilakukan oleh bagian internal audit perusahaan baik terhadap laporan keuangan dan rataan akuntansi perusahaan, maupun ketaatan terhadap kebijakan manajemen yang telah ditentukan.

Tunggal (2005:1) menyatakan internal audit adalah serangkaian proses dan teknik yang dilakukan oleh karyawan intern suatu organisasi untuk meyakinkan manajemen, secara tangan pertama, observasi di tempat, apakah.

a. Pengendalian manajemen yang ada telah cukup memuaskan dan dibina secaa efektif.

b. Catatan dan laporan keuangan, akuntansi dan lainnya menggambarkan dengan tepat dan segera kegiatan dan hasil yang sebenarnya.

c. Setiap bagian, seksi atau unit lainnya bekerja sesuai rencana, kebijakan dan prosedur yang dipertanggungjawabkan kepadanya.

Mulyadi (2004:86-87) menyatakan prosedur audit terdiri.

1. Inspeksi

2. Pengamatan (Observation)

3. Permintaan Keterangan (Enquing)

4. Konfirmasi

5. Penelusuran (Tracing)

6. Pemeriksaan Bukti Pendukung (Voucing)

7. Penghitungan (Counting)

8. Scanning

9. Pelaksanaan Ulang (Reperforming)

10. Teknik Audit Berbantuan Komputer (Computer Assiten Audit Techniques).

Arens (2010:3) menyatakan, jenis-jenis auditor adalah sebagai berikut:

1. Kantor akuntan publik terdaftar, yaitu auditor yang mempunyai tanggung jawab atas laporan keuangan historis yang dipublikasikan dari semua perusahaan yang sahamnya diperdagangkan dibursa saham, mayoritas perusahan besar lainnya, serta banyak perusahaan berskala kecil dan organisasi non komersil.

2. Auditor pemerintah, yaitu auditor yang mempunyai tanggung jawab mengevaluasi efisiensi, efektifitas, dan keekonomisan dari program atau proyek permerintah.

3. Auditor pajak, yaitu auditor yang bertanggung jawab melaksanakan pemeriksaan atas tercapainya penerimaan negara dari sektor perpajakan dan penegakan hukum dalam pelaksanaan perpajakan. 
4. Auditor intern, yaitu auditor yang bekerja disuatu perusahaan untuk melaksanaan audit bagi kepentingan manejemen perusahaan.

\section{Auditor Sektor Publik}

Bastian (2003:66) menyatakan, audit sektor publik adalah jasa penyelidikan bagi masyarakat atas organisasi publik dan politikus yang sudah mereka bayar. Audit sektor publik dilakukan pada organisasi pemerintah yang bersifat nirlaba seperti sektor pemerintah daerah (Pemda), BUMN, BUMD dan instansi lainnya yang berkaitan dengan pengelolaan aset kekayaan negara. Sedangkan kalau audit pada sektor bisnis, dilakukan pada perusahaan-perusahaan milik swasta yang bersifat mencari laba.

Media akuntansi (2005:37), dalam pengertian yang umum khususnya bagi dunia akuntansi di negaranegara maju, organisasi sektor publik terbagi dalam tiga kelompok besar, yaitu.

a. Pemerintah Pusat, yang terdiri dari Departemen dan Badan-badan di bawah Pemerintah Eksekutif.

b. Industri atau perusahaan untuk kepentingan publik atau masyarakat luas.

c. Pemerintah Daerah, baik ditingkat propinsi maupun kabupaten/kota, serta lembaga-lembaganya.

Arens (2010:4) mengungkapkan Standar Profesional Akuntan Publik adalah sebagai berikut.

a. Standar Umum

1. Audit harus dilaksanakan oleh seseorang atau lebih yang memiliki keahlian dan pelatihan teknis yang cukup sebagai auditor.

2. Dalam semua hal yang berhubungan dengan penugasan, independensi dalam sikap mental harus dipertahankan oleh auditor.

3. Dalam pelaksanaan audit dan pelaporannya, auditor wajib menggunakan kemahiran profesionalnyadengan cermat dan seksama.

b. Standar Pekerjaan Lapangan

1. Pekerjaan harus direncanakan sebaik-baiknya dan jika digunakan asisten harus disupervisi dengan semestinya.

2. Pemahaman yang memadai atas struktur pengendalian intern harus diperoleh untuk merencanakan audit dan menentukan sifat, saat dan lingkup pengujian yang akan dilakukan.

3. Bahan bukti kompeten yang memadai harus melalui inspeksi, pengamatan, pengajuan pertanyaan, konfirmasi, sebagai dasar yang memadai untuk menyatakan pendapat atas laporan keuangan hasil audit.

c. Standar Pelaporan

1. Laporan audit harus menyatakan apakah laporan keuangan telah disusun sesuai dengan prinsip akuntansi yang berlaku umum.

2. Laporan audit harus menunjukkan keadaan yang didalamnya prinsip akuntansi tidak secara konsisten diterapkan dalam penyusunan laporan keuangan periode berjalan sesuai dengan prinsip akuntansi yang diterapkan dalam dalam periode sebelumnya.

3. Pengungkapan informasi dalam laporan keuangan harus dipandang memadai, kecuali dinyatakan lain dalam laporan audit.

4. Laporan audit harus memuat pernyataan pendapat mengenai laporan keuangan secara keseluruhan atau asersi bahwa pernyataan demikian tidak dapat diberikan.

\section{Pengaruh Pengalaman Terhadap Kekeliruan}

Pengaruh pengalaman dan pengetahuan sangat penting diperlukan dalam rangka kewajiban seorang pemeriksa terhadap tugasnya untuk memenuhi standar umum audit.Pengetahuan seorang auditor dimulai dengan pendidikan formal, yang diperluas melalui pengalaman-pengalaman selanjutnya dalam praktik audit.Untuk memenuhi persyaratan sebagai seorang profesional, auditor harus menjalani pelatihan teknis yang cukup Noviyani dan Bandi (2009). Berdasarkan penelitian bahwa pengalaman audit dapat mengurangi efek keyakinan pada pertimbangan auditor. Sesuai dengan teori yang menyatakan bahwa auditor yang lebih berpengalaman tidak sensitif terhadap tipe bukti tertentu, dalam hal bukti yang bersifat negatif atau positif. Hasil penelitian itu memiliki manfaat bagi praktik audit yang sudah seharusnya kantor akuntan menekankan pada aspek telaah kepada setiap staf auditor, sehingga pertimbangan yang dibuatnya bisa bebas dari faktor urutan bukti. Penelitian yang hampir sama dilakukan oleh Noviyani dan Bandi(2009)yang menyimpulkan bahwa pengalaman akan berpengaruh terhadap pengetahuan auditor tentang jenis kekeliruan. Keahlian audit merupakan suatu kemampuan untuk mengetahui kekeliruan yang merupakan salah satu bagian dari kompetensi auditor. 


\section{Penggunaan Intuisi Dalam Mendeteksi Kekeliruan}

Pengalaman juga berpengaruh pada tingkat penggunaan intuisi individu dalam mengambil keputusan. Intuisi menuju pada kemampuan memberi kode, menyortir, dan mengakses kebermaknaan atau relevansi hasil keputusan masa lalu secara efisien. Intuisi bukan merupakan suatu daya kognitif yang terlahir atau kemampuan yang digunakan sesuai kehendak, melainkan suatu kemampuan belajar dari pengalaman Noviyani dan Bandi (2009).

\section{Konsep Kemampuan Mendeteksi Kekeliruan}

Noviyani dan Bandi (2009) menyatakan faktor-faktor yang diperkirakan mempengaruhi perkembangan pengetahuan auditor itu adalah pengalaman audit, diskusi mengenai audit dengan rekan sekerja, pengawasan dan review pekerjaan oleh akuntan pemeriksa pengawas, program pelatihan, tindak lanjut perencanaan audit, dan penggunaan pedoman audit.

\section{Penelitian Terdahulu}

Tabel.1. Penelitian Terdahulu

\begin{tabular}{|c|c|c|c|c|c|c|}
\hline $\begin{array}{c}\text { Nama } \\
\text { peneliti/ } \\
\text { Tahun }\end{array}$ & $\begin{array}{c}\text { Judul } \\
\text { penelitian }\end{array}$ & Tujuan & $\begin{array}{c}\text { Metode } \\
\text { Penelitian }\end{array}$ & Hasil Penelitian & Perbedaan & Persamaan \\
\hline $\begin{array}{l}\text { Herawaty } \\
\text { dan } \\
\text { Susanto } \\
(2009)\end{array}$ & $\begin{array}{l}\text { Pengaruh } \\
\text { Profesionalisme, } \\
\text { Pengetahuan } \\
\text { Mendeteksi } \\
\text { Kekeliruan, dan } \\
\text { Etika Profesi } \\
\text { Terhadap } \\
\text { Pertimbangan } \\
\text { Tingkat } \\
\text { Materialitas } \\
\text { Akuntan Publik }\end{array}$ & $\begin{array}{l}\text { Untuk } \\
\text { mendapatkan } \\
\text { bukti empiris } \\
\text { tentang pengaruh } \\
\text { profesionalisme, } \\
\text { pengetahuan } \\
\text { akuntan publik } \\
\text { dalam } \\
\text { mendeteksi } \\
\text { kekeliruan dan } \\
\text { etika profesi } \\
\text { terhadap } \\
\text { pertimbangan } \\
\text { tingkat } \\
\text { materialitas } \\
\text { akuntan publik } \\
\text { dalam proses } \\
\text { pemeriksaan } \\
\text { laporan keuangan }\end{array}$ & $\begin{array}{l}\text { Regresi } \\
\text { berganda }\end{array}$ & $\begin{array}{l}\text { profesionalisme, } \\
\text { pengetahuan dalam } \\
\text { mendeteksi } \\
\text { kekeliruan dan etika } \\
\text { profesi berpengaruh } \\
\text { secara signifikan dan } \\
\text { positif terhadap } \\
\text { pertimbangan tingkat } \\
\text { materialitas akuntan } \\
\text { publik dalam proses } \\
\text { pemeriksaan laporan } \\
\text { keuangan }\end{array}$ & $\begin{array}{l}\text { Peneliti sebelumnya } \\
\text { meneliti } \\
\text { profesionalisme, } \\
\text { pengetahuan akuntan } \\
\text { publik dalam } \\
\text { mendeteksi kekeliruan } \\
\text { dan etika profesi } \\
\text { terhadap pertimbangan } \\
\text { tingkat materialitas } \\
\text { akuntan publik dalam } \\
\text { proses pemeriksaan } \\
\text { laporan keuangan }\end{array}$ & Alat analisis \\
\hline $\begin{array}{l}\text { Noviyani } \\
\text { dan Bandi } \\
(2009)\end{array}$ & $\begin{array}{l}\text { Pengaruh } \\
\text { Pengalaman dan } \\
\text { Pelatihan } \\
\text { terhadap } \\
\text { Struktur } \\
\text { Pengetahuan } \\
\text { Auditor Tentang } \\
\text { Kekeliriuan }\end{array}$ & $\begin{array}{l}\text { Untuk } \\
\text { mengetahui } \\
\text { pengaruh } \\
\text { Pengalaman } \\
\text { dan pelatihan } \\
\text { terhadap } \\
\text { struktur } \\
\text { pengetahuan } \\
\text { Auditor tentang } \\
\text { Kekeliriuan. }\end{array}$ & $\begin{array}{l}\text { Regresi } \\
\text { berganda }\end{array}$ & $\begin{array}{l}\text { Pengalaman } \\
\text { mempunyai pengaruh } \\
\text { yang positif dan } \\
\text { signifikan terhadap } \\
\text { pengendalian jika } \\
\text { suatu kekeliruan } \\
\text { terjadi. Tidak ada } \\
\text { pengaruh yang } \\
\text { signifikan antara } \\
\text { pelatihan dengan } \\
\text { jenis-jenis kekeliruan } \\
\text { yang berbeda yang } \\
\text { diketahui auditor }\end{array}$ & $\begin{array}{l}\text { Penelitian ini tidak } \\
\text { meneliti tentang } \\
\text { pelatihan auditor }\end{array}$ & alisis \\
\hline
\end{tabular}

\section{Jenis Penelitian}

\section{METODE PENELITIAN}

Penelitian ini merupakan penelitian kausalitas. Sugiyono (2010:100) menyatakan penelitian kausalitas merupakan penelitian yang bertujuan untuk mengetahui pengaruh dua variabel atau lebih. 


\section{Tempat dan Waktu Penelitian}

Penelitian ini dilakukan kantor Inspektorat Provinsi Sulawesi Utara yang berada di Jalan 17 Agustus Manado, Sulawesi Utara. Periode waktu penelitian dimulai dari Januari sampai dengan April 2013.

\section{Prosedur Penelitian}

1. Penulis melakukan kajian awal dengan melakukan studi literatur baik studi kepustakaan maupun membaca melalui internet.

2. Kemudian melakukan pengidentifikasian tentang masalah, merumuskannya, menetapkan tujuan/manfaat penelitian, kemudian membatasi masalah ke lingkup yang disesuaikan dengan penelitian saat ini.

3. Perancangan dan persiapan survai pada objek penelitian yang telah ditentukan, kemudian pengumpulan data baik primer maupun sekunder.

4. Melakukan pengolahan data, dan membahasnya.

5. Menarik kesimpulan dan memberikan saran-saran guna melengkapi penelitian.

\section{Populasi dan Sampel}

Adapun yang menjadi populasi dalam penelitian ini adalah para auditor pemerintah yang bekerja pada Inspektorat Provinsi Sulawesi Utara. Sugiyono (2010:56) menyatakan sampel adalah sebagian dari jumlah dan karakteristik yang dimiliki oleh populasi tersebut. Selanjutnya dari jumlah populasi yang ada kemudian diambil sampel sebanyak 50 orang responden berdasarkan asumsi atau pendapat yang menyatakan bahwa ukuran minimum sampel yang dapat diterima berdasarkan pada desain penelitian yang digunakan, maka minimal diambil sampel sebanyak 30 subjek secara metode acak sederhana (simple random sampling).

\section{Metode Pengumpulan Data}

Pengumpulan data dalam penelitian ini diperlukan melalui beberapa kegiatan yaitu peneliti melakukan wawancara langsung dan membagikan kuisioner pada auditor pemerintah yang bekerja pada Inspektorat Provinsi Sulawesi Utara.

\section{Metode Analisa}

Penelitian ini akan menggunakan teknik analisis regresi ganda dengan menggunakan data yang diperoleh dengan bantuan kuesioner dari responden penelitian.

\section{Hasil Penelitian}

\section{HASIL PENELITIAN DAN PEMBAHASAN}

Sesuai dengan sumber data yang telah dijelaskan pada bagian metode penelitian, bahwa populasi dalam penelitian ini adalah pegawai pada Inspektorat Provinsi Sulawesi Utara Secara keseluruhan proses pengambilan data dalam penelitian ini berjalan cukup baik, dalam arti bahwa setiap responden cukup responsif dan bersikap sangat koperatif dalam memberikan informasi yang diperlukan oleh peneliti. Dalam menjawab pertanyaan yang berkaitan dengan variabel yang diteliti, pada umumnya responden memberikan jawaban yang objektif sehingga memungkinkan peneliti untuk memperoleh data yang sangat akurat.

\section{Hasil uji Validitas dan Reliabilitas}

Uji validitas dan reliabilitas dilakukan sebelum analisis regresi. Berikut akan disajikan hasil perhitungan uji validitas dan reliabilitas variabel pengalaman auiditor $\left(X_{1}\right)$ yang terdiri dari 5 pernyataan atau itemternyata hasil uji validitas untuk variabel pengalaman auditor dengan 5 butir item ternyata semuanya valid karena berada diatas nilai kritisnya $r_{\text {tabel }}=0,3610$ sehingga butir instrument tersebut dapat digunakan untuk mengukur variabel penelitian. Sedangkan uji reliabilitas diperoleh Alpha Cronbach $=0,837$ atau berada diatas nilai kritis yang disarankan sebesar 0,6 sehingga variabel pengalaman auditor dinyatakan reliabel. Hasil perhitungan uji validitas dan reliabilitas variabel penguunaan intuisiauditor $\left(\mathrm{X}_{2}\right)$ yang terdiri dari 5 pernyataan atau item ternyata hasil uji validitas untuk variabel penggunaan intuisi auditor dengan 5 butir item ternyata semuanya valid karena berada diatas nilai kritisnya $r_{\text {tabel }}=0,3610$ sehingga butir instrument tersebut dapat digunakan untuk mengukur variabel penelitian. Sedangkan uji reliabilitas diperoleh Alpha Cronbach $=0,750$ atau berada diatas nilai kritis yang disarankan sebesar 0,6 sehingga variabel penggunaan intuisi auditor dinyatakan reliabel. Hasil perhitungan uji validitas dan reliabilitas variabel mendeteksi kekeliruan (Y) yang terdiri dari 5 pernyataan atau item ternyata hasil uji validitas untuk variabel mendeteksi kekeliruan dengan 5 butir item ternyata semuanya valid karena berada diatas nilai kritisnya $r_{\text {tabel }}=0,3610$ sehingga butir instrument tersebut dapat digunakan untuk mengukur 
variabel penelitian. Sedangkan uji reliabilitas diperoleh Alpha Cronbach $=0,912$ atau berada diatas nilai kritis yang disarankan sebesar 0,6 sehingga variabel mendeteksi kekeliruan dinyatakan reliabel.

\section{Hasil Pengujian Hipotesis}

Uji t ini digunakan untuk mnegetahui apakah variabel independen (X) berpengaruh signifikan secara parsial terhadap variabel (Y). Berdasarkan hasil uji t ini didapat:

1. Variabel pengalaman auditor, nilai $t_{\text {hitung }}>t_{\text {tabel }}(5,612>1,685)$ dan nilai signifikansi $P=0,000<\alpha=0,05$. Hal ini menunjukan bahwa Ho ditolak dan Ha diterima, artinya pengalaman auditorberpengaruh dalam mendeteksi kekeliruan pada Inspektorat Provinsi Sulawesi Utara.

2. Variabel penggunaan intuisi auditor, nilai $t_{\text {hitung }}>t_{\text {tabel }}(1.838>1,685)$.dan nilai signifikansi $P=0,032<\alpha=$ 0,05 . Hal ini menunjukan bahwa Ho ditolak dan Ha diterima, artinya penggunaan intuisi auditorberpengaruh dalam mendeteksi kekeliruan pada Inspektorat Provinsi Sulawesi Utara.

Pengujian hipótesis secara bersama (uji F) dilakukan untuk mengetahui apakah variabel bebas secara simultan berpengaruh signifikan atau tidak terhadap variabel terikat. Didapat bahwa nilai $\mathrm{F}_{\text {hitung }}>\mathrm{F}_{\text {tabel }}$ $(18,312>2,370)$.dan nilai signifikansi $\mathrm{P}=0,000<\alpha=0,05$. Hal ini menunjukan bahwa Ho ditolak dan Ha diterima, artinya pengalaman dan penggunaan intuisi auditorsecara bersama-sama berpengaruh dalam mendeteksi kekeliruan pada Inspektorat Provinsi Sulawesi Utara.

\section{Pembahasan}

Berdasarkan hasil pengujian hipotesis secara parsial (uji t) diketahui bahwa pengalaman auditor memiliki nilai $t_{\text {hitung }}>t_{\text {tabel }}(5,612>1,685)$ dan nilai signifikansi $P=0,000<\alpha=0,05$. Hal ini menunjukan bahwa Ho ditolak dan Ha diterima, artinya pengalaman auditorberpengaruh dalam mendeteksi kekeliruan pada Inspektorat Provinsi Sulawesi Utara. Penggunaan intuisi auditormemiliki nilai $t_{\text {hitung }}>t_{\text {tabel }}(1.838>1,685)$.dan nilai signifikansi $\mathrm{P}=0,032<\alpha=0,05$. Hal ini menunjukan bahwa Ho ditolak dan Ha diterima, artinya penggunaan intuisi auditorberpengaruh dalam mendeteksi kekeliruan pada Inspektorat Provinsi Sulawesi Utara. Dan koefisien korelasi yang dihasilkanantara pengalaman auditor $\left(\mathrm{X}_{1}\right)$ dan penggunan intuisi auditor $\left(\mathrm{X}_{2}\right)$ dengan mendeteksi kekeliruan (Y) adalah sebesar 0,663 artinya pengalaman dan penggunaan intuisi auditor memiliki hubungan yang kuat dengan mendeteksi kekeliruan yaitu sebesar 66,2\%. Berdasarkan hasil penelitian, maka disimpulkan bahwa pengalaman dan penggunaan intuisi auditorberpengaruh dalam mendeteksi kekeliruan padaInspektorat Provinsi Sulawesi Utara. Pengalaman dan penggunaan intuisiauditor memiliki kontribusi tersendiri dalam usaha auditor untuk meningkatkan kemampuan mendeteksi kekeliruan dalam lingkungan audit. Dengan menyadari pernyatan tersebut maka sebagian besar auditor berusaha untuk manambahkan unsur pengalaman pada pengetahuan yang dimiliki dan penggunaan intuisi dalam proses audit. Hasil penelitian ini didukung teori dari Agus Hardjana (2001:46) yang menunjukkan bahwa ketika akuntan pemeriksa menjadi lebih berpengalaman maka, pertama, auditor menjadi sadar terhadap lebih banyak kekeliruan. Kedua, auditor memiliki salah pengertian yang lebih sedikit terhadap kekeliruan. Ketiga, auditor menjadi sadar mengenai kekeliruan yang lebih tidak lazim. Keempat, hal-hal yang terkait dengan penyebab kekeliruan seperti departemen tempat terjadi kekeliruan dan pelanggaran tujuan pengendalian internal menjadi relatif lebih menonjol. Auditor yang berpengalaman mampu mengingat lebih banyak kekeliruan-kekeliruan dan lebih sedikit jumlah kesalahan-kesalahan yang dilakukan. Auditor berpengalaman juga mengingat lebih banyak kekeliruankekeliruan yang tak lazim. Sedangkan penggunaan intuisi merujuk pada kemampuan untuk memberi kode, menyortir dan mengakses kebermaknaan atau relevansi hasil keputusan masa lalu secara efisien.

\section{Kesimpulan}

\section{PENUTUP}

Berdasarkan hasil analisa dan pembahasan yang telah dilakukan maka dapat ditarik beberapa kesimpulan sebagai berikut.

1. Pengalaman auditor berpengaruh dalam mendeteksi kekeliruan pada Inspektorat Provinsi Sulawesi Utara. 2. Penggunaan intuisi berpengaruh dalam mendeteksi kekeliruan pada Inspektorat Provinsi Sulawesi Utara.

\section{Saran} berikut.

Berdasarkan hasil penelitian yang dilakukan, maka beberapa hal yang dapat disarankan adalah sebagai

1. Menambah pengalaman agar auditor lebih tahu tentang jenis-jenis kekeliruan yang mungkin terjadi di lapangan dan hal-hal lain yang berhubungan dengan kekeliruan. 
2 Jika ingin lebih mendeteksi kekeliruan maka yang perlu diperhatikan adalah tingkat pendidikan harus ditingkatkan ke jenjang yang lebih tinggi.

\section{DAFTAR PUSTAKA}

Herawaty, Arleen ., Susanto, Yulius Kurnia. 2009. Profesionalisme, Pengetahuan Mendeteksi Kekeliruan, dan Etika Profesi Terhadap Pertimbangan Tingkat Materialitas Akuntan Publik. Skripsi. Trisakti School of Management. Jakarta.

Arens, Alvin A. 2010. Auditing. Prentice Hall. New Jersey.

Bastian, Indra. 2003. Akuntansi Sektor Publik di Indonesia. Edisi 7. BPFE. Yogyakarta.

Halim Abdul. 2004. Teori Akuntansi. Edisi kedua. Erlangga. Jakarta.

Media akuntansi. 2005 Edisi Juni Hal 37. Jakarta.

Mulyadi. 2004. Auditing. Salemba Empat. Jakarta.

Noviyani ., Bandi. 2009. Pengaruh Pengalaman dan Pelatihan terhadap Struktur Pengetahuan Auditor Tentang Kekeliriuan. Skripsi. UNS. Surakarta.

Republik Indonesia. Undang-Undang RI No. 32 thn 2004 tentang Otonomi Daerah. Jakarta.

Soekrisno, Agoes. 2002. Auditing oleh KAP. Jilid II. FE-UI. Jakarta.

Sugiyono. 2010. Metode Penelitian. CV Alfabeta. Bandung.

Tunggal, Amin Widjaja. 2005. Akuntansi Biaya, Ringkasan Teori Soal dan Jawab. Rineka Cipta. Jakarta.

Yusuf, Amir Abdi. 2004. Analisis Laporan Keuanagan. Liberty. Jakarta. 